\title{
Perumusan Strategi Rekomendasi UKM Pada Masa Pandemi Covid-19 (Studi kasus : UD Darmaji)
}

\author{
Albertus Daru Dewantoro', Aschensio Saogo ${ }^{2}$, \\ ${ }^{12}$ Teknik Industri, Teknik, Universitas Katolik Darma Cendika, \\ Jl. Dr. Ir. H. Soekarno No 201, Surabaya, 60117, Indonesia \\ chensaogo21@gmail.com'; albertus.daru@ukdc.ac.id ${ }^{2}$
}

\begin{abstract}
Abstrak
UD Darmaji merupakan salah satu UKM yang menerima pesanan pembuatan sandal dan sepatu. Beberapa tahun terakhir UD Darmaji mengalami penurunan produksi, terdapat beberapa penyebab penurunan produksi dari UD Darmaji diantaranya adalah kurangnya permintaan dan kurang tepatnya penyusunan strategi pemasaran dalam strategi pemasaran. Terdapat beberapa metode dan analisis yang digunakan dalam penelitian ini yaitu Analisis SWOT (Strength, Weaknesses, Opportunities, Threats), matriks IFE (Internal Factor Evaluation Matrix) dan EFE (Eksternal Factor Evaluation Matrix) serta AHP (Analitycal hierarchy process) yang digunakan untuk pembobotan serta QSPM (Quantitative Strategic Planning Matriks) untuk menentukan strategi apa saja yang akan dipilih. Hasil analisa didapatkan strategi melakukan penjualan secara online baik menggunakan sosial media maupun situs-situs jual beli secara online dengan perolehan nilai TAS (Total Atratctive Score) paling tinggi yakni 5,614, strategi meningkatkan kualitas packaging menjadi lebih baik dan lebih menarik bernilai TAS sebesar 5,336, dan strategi menjadikan tempat kerja menjadi lebih nyamann dengan menata ulang pabrik sehingga dapat terlihat lebih rapi dan bersih dan melakukan pernerapan 5R nilai TAS 5,242, yang akan di jadikan saran untuk UD Darmaji.
\end{abstract}

Kata kunci: SWOT, UKM, QSPM, IFE, EFE

\begin{abstract}
UD Darmaji is one of the SMEs that accepts orders for making sandals and shoes. In the last few years, UD Darmaji has experienced a decline in production, there are several causes for the decline in production from UD Darmaji, including the lack of demand and inaccurate formulation of marketing strategies in marketing strategies. There are several methods and analyzes used, namely SWOT analysis (Strength, Weaknesses, Opportunities, Threats), IFE matrix (Internal Factor Evaluation Matrix) and EFE (External Factor Evaluation Matrix) and AHP (Analitycal hierarchy process) which is used for weighting and QSPM (Quantitative Strategic Planning Matrix) to determine what strategies to choose. The results of the analysis show that the strategy of selling online using both social media and online buying and selling sites has the highest TAS (Total Attractive Score) value of 5,614, the strategy to improve the quality of packaging is better and more attractive, with a TAS value of 5,336, and a strategy to make the workplace more comfortable by rearranging the factory so that it looks tidier and cleaner and implementing the 5R TAS value of 5.242, which will be used as a suggestion for UD Darmaji.
\end{abstract}

Keywords: SWOT, SME's, QSPM, IFE, EFE.

\section{Pendahuluan}

Seiring dengan perkembangan zaman yang dimana teknologi serta peluang yang besar semakin berkembang menyebabkan persaingan bisnis yang ketat bagi perusahaan. Persaingan tersebut sangat rentan terjadi akibat mencari laba dan pastinya mencapai visi misi perusahaan. Perusahaan harus dapat mengetahui faktorfaktor yang berasal dari internal maupun eksternal dari perusahaan tersebut. Analisis Strength, Weaknesses, Opportunities, Threats selanjutnya disebut SWOT berguna dalam analisis situasional karena membatu pembuat keputusan untuk menilai lingkungan internal dan eksternal organisasi mereka (Sluismans et al., 2010), dengan analisis situasional ini, manajemen mendapatkan gambaran umum tentang sumber daya dan kapabilitas perusahaan yang dapat mereka andalkan untuk menangkap peluang, sementara pada saat yang sama, dapat mengantisipasi ancaman eksternal yang dapat mengganggu penjualan dan laba perusahaan (AlRefaie et al., 2016). Faktor internal meliputi kekuatan dan kelemahan suatu perusahaan sementara faktor eksternal adalah semua kejadian atau peristiwa yang terjadi diluar perusahaan yang dapat mempengaruhi kinerja perusahaan yang akan menjadi peluang dan ancaman bagi perusahaan (Nuary, 2016).

Strategi adalah upaya yang direncanakan untuk mencapai tujuan perusahaan (David, 2005). Dalam penyusunan strategi pemasaran ada beberapa metode dan analisis yang digunakan, salah satunya adalah Analisis SWOT. Analisis SWOT adalah salah satu alat yang digunakan dalam dunia bisnis untuk mengenali kemungkinan- kemungkinan yang terjadi yang 
berkaitan dengan inovasi baru dalam dunia bisnis (AlRefaie, 2016). Analisis SWOT memiliki keutungan atau manfaat untuk memperluas jaringan pemasaran, mengatasi permasalahan internal bisnis,dan lain-lain (Putri, 2014).

Rumusan Strategi yang dihasilkan melalui analisa SWOT terdiri dari beberapa alternatif yang belum tentu dapat diimplementasikan semuanya, sehingga perlu upaya pemilihan alternatif yang sesuai dengan kemampuan dan skala prioritas perusahaan, maka metode Quantitative Strategic Planning Matriks (QSPM) dapat membantu dalam evaluasi pilihan alternatif secara objektif, menetapkan daya tarik relatif dari tindakan alternatif yang layak dan memumutuskan strategi mana yang terbaik (Zulkarnain, 2018). Keunggulan dari QSPM adalah dapat diamati secara beruntun dan bersamaan serta memperkecil kemungkinan bahwa faktor-faktor utama akan akan terlewatkan namun membutuhkan penilaian secara intuitif dan asumsi yang mendasar (Putri, 2014).

Pemasaran merupakan suatu konsep yang menyeluruh yang meliputi penjualan, perdagangan, dan distribusi (Astina \& Mawardi, 2016). Dalam upaya meningkatkan penjualan dan laba perusahaan, aktifitas pemasaran sangat penting untuk diperhatikan dan perlu dirumuskan dalam bentuk perencanaan strategi (Maulidya et al., 2018). UKM memiliki permasalahan yang berbeda satu dengan yang lain, ada yang mampu berkembang, ada yang hanya mampu bertahan, dan tidak sedikit yang gagal. Usaha kecil menengah (UKM) bisa dikatakan memiliki pengaruh terhadap perekonomian daerah bahkan turut menpengaruhi perekonomian Indonesia (Purwanti, 2013). Pemasaran yang dirumuskan secara formal dalam perencanaan strategis sangat dibutuhkan bagi UKM. UD Darmaji merupakan salah satu UKM yang menerima pesanan pembuatan sandal dan sepatu dimana UD Darmaji ini berlokasi di Jl. Kolonel sugiono wedoro candi RT 02/RW 04 No 42 Waru Sidoarjo dan sudah berdiri dari tahun 1988. UD Daramaji mengalami penurunan produksi, berikut data dari produksi UD Darmaji dari tahun 2015- 2020 :

Tabel 1. Data produksi UD Darmaji

\begin{tabular}{lrrrrr}
\hline Tahun & $\begin{array}{c}\text { Sandal } \\
\text { anak } \\
\text { laki-laki }\end{array}$ & $\begin{array}{c}\text { Sandal } \\
\text { anak } \\
\text { perempuan }\end{array}$ & $\begin{array}{c}\text { Sandal } \\
\text { dewasa } \\
\text { laki-laki }\end{array}$ & $\begin{array}{c}\text { Sandal } \\
\text { dewasa } \\
\text { perempuan }\end{array}$ & Total \\
\hline 2015 & 10.000 & 10.000 & 8.000 & 6.000 & 34.000 \\
2016 & 9.000 & 8.000 & 8.000 & 8.000 & 33.000 \\
2017 & 8.000 & 9.000 & 6.000 & 7.000 & 30.000 \\
2018 & 7.000 & 7.000 & 7.000 & 7.000 & 28.000 \\
2019 & 7.000 & 7.000 & 6.000 & 6.000 & 26.000 \\
2020 & 7.000 & 7.000 & 5.000 & 5.000 & 24.000
\end{tabular}

Produk sandal UD Darmaji memiliki segmentasi pasar tertentu, berdasarkan segmentasi demografinya produk sandal ini diperuntukkan bagi anak-anak mulai dari usia 6 tahun hinga orang dewasa baik itu pria ataupun wanita. Produk telah dipasarkan kewilayah Jawa Timur dan sekitarnya, Bali dan Lombok. Produk sandal UD Darmaji ditawarkan dengan harga yang terjangkau, dengan masyrakat menengah kebawah sebagai target segmentasinya, hal ini dimana berkaitan dengan harga yang ditawarkan kepada calon pembeli relatif murah dan terjangkau namun tetap memiliki varian warna dan desain yang menarik serta nyaman saat digunakan.

Tujuan penelitian ini dilaksanakan adalah, merumuskan usulan strategi dan indikator keberhasilannya untuk meningkatkan penjualan UD Darmaji melalui pendekatan analisis dengan mengintegrasikan metode SWOT dan QSPM agar rumusan alternatif strategi yang direkomendasikan dapat menseleksi alternatif strategi yang dirumuskan berdasarkan skala prioritas dengan mempertimbangkan expert jugment pelaku usaha dan sumberdaya yang dimiliki perusahaan agar strategi yang direkomendasikan dapat benar-benar terimplementasi dan diharapkan mampu meningkatkan tingkat penjualan produk UD Darmaji.

\section{Metode Penelitian}

Penelitian ini dilaksanakan melalui tiga tahap analisis penelitian dengan mengacu pada penelitian yang dilakukan oleh Mujiastuti et al., (2019) dan Achmadi et al., (2020) yaitu tahap pertama adalah The Input Stage yang dilakukan dalam rangka penyusunan matriks Internal Factor Evaluation (IFE) dan External Factor Evaluation (EFE) dimana sebelumnya dilakukan in-depth interview kepada pelaku usaha untuk mengidentifikasi faktor internal yang terdiri dari faktor yang dikategorikan faktor kekuatan dan faktor kelemahan, serta faktor eksternal yaitu peluang dan ancaman. Pemberian bobot terhadap setiap faktor dilakukan dengan menggunakan paired comparison atau perbandingan berpasangan (Zulkarnain et al., 2018) dan memberikan rating atau peringkat terhadap faktor strategis yang telah diuraikan. Bobot dikalikan rating menentukan nilai tertimbang dari faktor lalu dijumlahkan menjadi total nilai tertimbang.

Tahap kedua adalah The Matching Stage, dimana faktor eksternal dan eksternal disatukan dalam matriks Internal External (IE) dengan sumbu X untuk IFE dan sumbu Y untuk EFE. Pada tahapan ini juga dilakukan menyusun matriks SWOT dengan cara menghubungkan faktor-faktor yang merupakan kekuatan dan peluang untuk menghasilkan rekomendasi strategi SO; menghubungkan kekuatan dan ancaman yang merupakan usulan strategi ST; menghubungkan kelemahan dan peluang yang merupakan strategi WO; dan menghubungkan kelemahan dan ancaman untuk menghasilkan usulan strategi WT. 
Tahap ketiga adalah Decision Stage melalui pendekatan analisis QSPM. Analisis QSPM digunakan dalam upaya menunjukkan strategi alternatif yang terbaik untuk dipilih.

\section{Hasil dan Pembahasan}

Sesuai dengan metode penelitian yang ditetapkan, analisis dan pembahasan penelitian ini adalah sebagai berikut :

\subsection{Tahap The Input Stage}

Melalui pendekatan in-depth interview dengan pelaku usaha UD Darmaji, diperoleh faktor-faktor SWOT sebagai berikut :

\section{Internal}

a) Strength ( kekuatan )

- Memiliki SDM yang berpengalaman dibidangnya

- Harga yang ditawarkan dapat dijangkau

- Beberapa proses menggunakan mesin

- Produk memiliki banyak varian warna dan motif

- Lokasi strategis mudah mendapatkan bahan baku

- $\quad$ Alat dan gedung milik sendiri

b) Weakness ( kelemahan )

- Menajemen keuangan yang masih bersifat konvesional

- Brand kurang dikenal oleh banyak masyrakat

- Kurangnya promosi atau periklanan

- Jumlah SDM yang kurang

- Kondisi tempat kerja kurang nyaman

- Packaging kurang menarik

- Visi dan Misi belum ada

\section{Eksternal}

a) Opportunities ( peluang )

- Bahan baku yang mudah didapat

- Pemerintah telah menyediakan fasilitas untuk UKM berupa kredit usaha rakyat

- Memanfaatkan teknologi dengan melakukan penjualan online

- Pertumbuhan jumlah penduduk

b) Threat ( ancaman )

- Tingginya daya saing usaha sandal dikawasan wedoro

- Keadaan ekonomi yang tidak stabil yang menyebabkan harga bahan baku juga ikut naik turun atau tidak stabil

- Pandemi Covid 19 yang membuat produksi berhenti serta penurunan daya beli

- Peraturan pemerintah bisa berubah kapan saja

Pemberian bobot terhadap setiap faktor dilakukan dengan menggunakan paired comparison atau perbandingan berpasangan dan memberikan rating atau peringkat terhadap faktor strategis, lalu bobot dikalikan rating menentukan nilai tertimbang dari faktor lalu dijumlahkan menjadi total nilai tertimbang. Aktifitas pembobotan dan pemberian rating menggunakan pendekatan expert judgment. Adapun matrik IFE dan EFE adalah sebagai berikut :

Tabel 2. Matriks IFE

\begin{tabular}{lccc}
\hline Faktor Internal & Bobot & Rating & Score \\
\hline Kekuatan & & & \\
\hline $\begin{array}{l}\text { Memiliki SDM } \\
\text { berpengalaman dibidangnya }\end{array}$ & 0,062 & 2 & 0,124 \\
\hline $\begin{array}{l}\text { Harga yang ditawarkan dapat } \\
\text { dijangkau }\end{array}$ & 0,099 & 3 & 0,297 \\
\hline $\begin{array}{l}\text { Beberapa proses menggunakan } \\
\text { mesin }\end{array}$ & 0,051 & 2 & 0,102 \\
\hline $\begin{array}{l}\text { Produk memiliki banyak varian } \\
\text { warna dan motif }\end{array}$ & 0,086 & 2 & 0,172 \\
\hline $\begin{array}{l}\text { Lokasi strategis mudah } \\
\text { mendapatkan bahan baku }\end{array}$ & 0,066 & 2 & 0,132 \\
\hline $\begin{array}{l}\text { Alat dan gedung milik sendiri } \\
\text { Kelemahan }\end{array}$ & 0,068 & 2 & 0,136 \\
\hline $\begin{array}{l}\text { Menajemen keuangan yang masih } \\
\text { bersifat konvesional }\end{array}$ & 0,055 & 2 & 0,11 \\
\hline $\begin{array}{l}\text { Brand kurang dikenal oleh banyak } \\
\text { masyrakat }\end{array}$ & 0,089 & 2 & 0,178 \\
\hline $\begin{array}{l}\text { kurangnya promosi atau periklanan } \\
\text { Jumlah SDM yang kurang }\end{array}$ & 0,086 & 3 & 0,258 \\
\hline $\begin{array}{l}\text { Kondisi tempat kerja kurang } \\
\text { nyaman }\end{array}$ & 0,063 & 3 & 0,189 \\
\hline $\begin{array}{l}\text { Packaging kurang menarik } \\
\text { Visi dan misi tidak ada }\end{array}$ & 0,065 & 2 & 0,13 \\
\hline & 0,137 & 3 & 0,411 \\
\hline
\end{tabular}

Tabel 3. Matriks EFE

\begin{tabular}{|c|c|c|c|}
\hline Faktor Eksternal & Bobot & Rating & Score \\
\hline \multicolumn{4}{|l|}{ Peluang } \\
\hline Bahan baku yang mudah didapat & 0,101 & 4 & 0,404 \\
\hline $\begin{array}{l}\text { Memanfaatkan teknologi dengan } \\
\text { melakukan penjualan online }\end{array}$ & 0,11 & 3 & 0,33 \\
\hline $\begin{array}{l}\text { Pemerintah telah menyediakan } \\
\text { fasilitas untuk } \\
\text { usaha rakyat }\end{array}$ & 0,121 & 3 & 0,363 \\
\hline Pertumbuhan jumlah penduduk & 0,09 & 3 & 0,27 \\
\hline \multicolumn{4}{|l|}{ Ancaman } \\
\hline $\begin{array}{l}\text { Tingginya daya saing usaha sandal } \\
\text { dikawasan wedoro }\end{array}$ & 0,1 & 3 & 0,3 \\
\hline $\begin{array}{l}\text { Keadaan ekonomi yang tidak stabil } \\
\text { yang menyebabkan } \\
\text { harga bahan baku juga ikut naik turun } \\
\text { atau tidak stabil }\end{array}$ & 0,137 & 2 & 0,274 \\
\hline $\begin{array}{l}\text { Pandemi Covid } 19 \text { yang membuat } \\
\text { produksi berhenti serta penurunan } \\
\text { daya beli }\end{array}$ & 0,274 & 2 & 0,548 \\
\hline $\begin{array}{l}\text { Peraturan pemerintah bisa berubah } \\
\text { kapan saja }\end{array}$ & 0,066 & 2 & 0,132 \\
\hline & 1,000 & & $\mathbf{0 , 1 1 3}$ \\
\hline
\end{tabular}

\subsection{Tahap The Matching Stage}

Faktor eksternal (IFE) dan eksternal (EFE) disatukan dalam matriks Internal External (IE) dengan sumbu X untuk IFE dan sumbu Y untuk EFE. Untuk nilai Total pada bobot harus berjumlah 1 dan total 
score pada total pada IFE didapat dari total nilai kekuatan dikurangi total nilai kelemahan maka didapatlah nilai total IFE -0,044, nilai total ini menunjukan nilai pada sumbu X, sementara total pada EFE yang menunjukkan nilai pada sumbu Y adalah $+0,113$, sehingga posisi strategis UD Darmaji pada koordinat (-,044; 0,113).

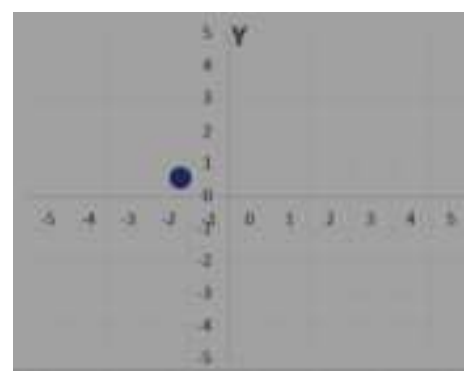

Gambar 1. Kuadaran SWOT

Kuadran IE menjelaskan posisi UD Darmaji adalah berada di bawah rata-rata untuk aspek internal namun masih memiliki peluang terbuka bagi perusahaan sehingga mendukung strategi trun-around. Strategi trun-around adalah strategi untuk membalikkan penurunan profitabilitas kembali menuju pemulihan dan mencapai masa depan yang berkelanjutan. Perusahaan dalam krisis membutuhkan tindakan drastis dan restrukturisasi untuk menghasilkan perubahan haluan, tindakan tersebut dapat berupa merancang strategi baru untuk meningkatkan kinerja operasi bisnis secara lebih agresif, termasuk dalam hal efisiensi, kualitas, inovasi, dan responsifitas pelanggan. Kebutuhan akan strategi turn-around juga dapat muncul karena adanya tekanan lingkungan eksternal seperti perubahan dalam selera dan preferensi konsumen, perubahan dalam kebijakan pemerintah, permintaan jenuh terhadap produk, ancaman dari produk pengganti (Shahri \& Sarvestani, 2020). Matriks SWOT strategi turn-around UD Darmaji adalah sebagai berikut :

Tabel 4. Matriks SWOT dan Alternatif Strategi

\begin{tabular}{|c|c|c|c|c|c|}
\hline & \multicolumn{4}{|r|}{ Kelemahan } \\
\hline & & S1 & $\begin{array}{l}\text { Memiliki SDM yang berpengalaman } \\
\text { dibidangnya }\end{array}$ & W1 & $\begin{array}{l}\text { Menajemen keuangan yang masih bersifat } \\
\text { konvesional }\end{array}$ \\
\hline & & S2 & Harga yang ditawarkan dapat dijangkau & W2 & Brand kurang dikenal oleh banyak masyrakat \\
\hline & & S3 & Beberapa proses menggunakan mesin & W3 & kurangnya promosi atau periklanan \\
\hline & & S4 & $\begin{array}{l}\text { Produk memiliki banyak varian warna dan } \\
\text { motif }\end{array}$ & W4 & Jumlah SDM yang kurang \\
\hline & & S5 & $\begin{array}{l}\text { Lokasi strategis mudah mendapatkan bahan } \\
\text { baku }\end{array}$ & W5 & Kondisi tempat kerja kurang nyaman \\
\hline & & \multirow[t]{2}{*}{ S6 } & \multirow[t]{2}{*}{ Alat dan gedung milik sendiri } & W6 & Packaging kurang menarik \\
\hline & & & & W7 & Visi dan Misi tidak tersosialisasikan \\
\hline Kode & Peluang & & Strategi SO & & Strategi WO \\
\hline $\mathrm{O} 1$ & $\begin{array}{l}\text { Bahan baku yang mudah } \\
\text { didapat }\end{array}$ & \multirow[t]{2}{*}{ SO1 } & \multirow{2}{*}{$\begin{array}{l}\text { Mempertahankan harga agar tetap } \\
\text { terjangkau } \\
\text { dengan menjaga hubungan terhadap } \\
\text { supllier sehingga mendapatkan harga bahan } \\
\text { baku yang murah (S5, O1) }\end{array}$} & WO1 & $\begin{array}{l}\text { Menjadikan tempat kerja menjadi lebih } \\
\text { nyamann } \\
\text { dengan menata ulang pabrik sehingga dapat } \\
\text { terlihat lebih rapi dan bersih dan melakukan } \\
\text { pernerapan 5R (W5, W7, O4) }\end{array}$ \\
\hline $\mathrm{O} 2$ & Memanfaatkan teknologi & & & WO2 & $\begin{array}{l}\text { Mengubah sistem keuangan dengan } \\
\text { memanfaatkan } \\
\text { teknologi yang ada }(\mathrm{W} 1, \mathrm{O} 2)\end{array}$ \\
\hline $\mathrm{O} 3$ & $\begin{array}{l}\text { Pemerintah telah } \\
\text { menyediakan fasilitas untuk } \\
\text { UKM berupa kredit usaha } \\
\text { rakyat }\end{array}$ & \multirow[t]{2}{*}{$\mathrm{SO} 2$} & \multirow{2}{*}{$\begin{array}{l}\text { Melakukan penjualan secara online baik } \\
\text { menggunakan sosial media maupun } \\
\text { situs-situs jual beli secara online ( } \mathrm{S} 1 \text {, } \\
\mathrm{S} 4, \mathrm{O} 2)\end{array}$} & \multirow[t]{2}{*}{ WO3 } & \multirow[t]{2}{*}{$\begin{array}{l}\text { Mencoba ikut dalam pemeran-pameran UKM } \\
\text { yang diselenggarakan Pemerindah daerah/ } \\
\text { Provinsi (W2, W3, O3) }\end{array}$} \\
\hline $\mathrm{O} 4$ & $\begin{array}{l}\text { Pertumbuhan jumlah } \\
\text { penduduk }\end{array}$ & & & & \\
\hline Kode & Ancaman & & Strategi ST & & Strategi WT \\
\hline $\mathrm{T} 1$ & $\begin{array}{l}\text { Tingginya daya saing usaha } \\
\text { sandal } \\
\text { dikawasan wedoro }\end{array}$ & \multirow[b]{2}{*}{ ST1 } & \multirow[b]{2}{*}{$\begin{array}{l}\text { Menambah variasi bentuk sandal seperti } \\
(\mathrm{S} 2, \mathrm{~T} 1, \mathrm{~T} 2) \\
\text { sandal gunung }\end{array}$} & \multirow[b]{2}{*}{ WT1 } & \multirow[b]{2}{*}{$\begin{array}{l}\text { Mengisih kekurangan SDM dan melakukan } \\
\text { identifikasi kebutuhan pelatihan personel dalam } \\
\text { meningkatkan kompetensi kerja }(\mathrm{W} 4, \mathrm{~T} 4)\end{array}$} \\
\hline $\mathrm{T} 2$ & $\begin{array}{l}\text { Keadaan ekonomi yang } \\
\text { tidak stabil yang } \\
\text { menyebabkan } \\
\text { harga bahan baku juga ikut } \\
\text { naik turun atau tidak stabil }\end{array}$ & & & & \\
\hline T3 & Kondisi wabah VIRUS & \multirow{3}{*}{ ST2 } & \multirow{3}{*}{$\begin{array}{l}\text { Melakukan perwatan terhadap alat dan (S3, } \\
\text { S6, T3) } \\
\text { gedung }\end{array}$} & \multirow{3}{*}{ WT2 } & \multirow{3}{*}{$\begin{array}{l}\text { Meningkatkan kualitas packaging menjadi lebih } \\
\text { baik } \\
\text { dan lebih menarik serta membuat Visi dan Misi } \\
(\mathrm{W} 6, \mathrm{~T} 1)\end{array}$} \\
\hline 15 & & & & & \\
\hline $\mathrm{T} 4$ & $\begin{array}{l}\text { Peraturan pemerintah bisa } \\
\text { berubah } \\
\text { kapan saja }\end{array}$ & & & & \\
\hline
\end{tabular}

\subsection{Tahap Decision Stage}

Melalui pendekatan analisis QSPM strategi alternatif yang terbaik akan dipilih.
Pada perhitungan QSPM terdapat faktor-faktor internal dan eksternal yang diketegorikan ke dalam SWOT, nilai bobot yang dapat dilihat pada matrik IFE 
dan EFE serta nilai AS (Attractiveness Scores) yang ditentukan dengan mengevaluasi masing-masing faktor internal atau eksternal kunci, satu pada suatu saat tertentu, dan mengajukan pertanyaan, "Apakah faktor ini memengaruhi pilihan strategi yang dibuat?" Jika jawabannya ya, maka strategi tersebut harus dibandingkan secara relatif terhadap faktor kunci tersebut. Secara spesifik, Nilai Daya Tarik harus diberikan untuk masing-masing strategi untuk mengindikasikan daya tarik relatif dari satu strategi atas strategi lainnya, dengan mempertimbangkan faktor tertentu. Jangkauan untuk Nilai Daya Tarik adalah $1=$ tidak menarik, 2 = agak menarik, 3 = cukup menarik, $4=$ sangat menarik, Sementara nilai TAS (Total Attractiveness Scores) didapatkan dari hasil pengalian nilai Bobot dan nilai AS (Attractiveness Scores).

Tabel 5. Perhitungan QSPM

\begin{tabular}{|c|c|c|c|c|c|c|c|c|c|c|c|c|c|c|c|c|c|c|c|}
\hline \multicolumn{2}{|c|}{ Alternatif Strategi } & \multicolumn{2}{|c|}{ so1 } & \multicolumn{2}{|c|}{$\mathrm{sO} 2$} & \multicolumn{2}{|c|}{ w01 } & \multicolumn{2}{|c|}{ w02 } & \multicolumn{2}{|c|}{ wo3 } & \multicolumn{2}{|c|}{ ST1 } & \multicolumn{2}{|c|}{ ST2 } & \multicolumn{2}{|c|}{ WT1 } & \multicolumn{2}{|c|}{ WT2 } \\
\hline Kode SWOT & Bobot & AS & TAS & AS & TAS & AS & TAS & AS & TAS & AS & TAS & AS & TAS & AS & TAS & AS & TAS & AS & TAS \\
\hline S1 & 0,062 & 4 & 0,248 & 4 & 0,248 & 2 & 0,124 & 2 & 0,124 & 2 & 0,124 & & 0,186 & 2 & 0,124 & 2 & 0,124 & 2 & 0,124 \\
\hline S2 & 0,099 & 2 & 0,198 & 3 & 0,297 & 2 & 0,198 & 2 & 0,198 & 2 & 0,198 & 7 & 0,396 & 3 & 0,297 & 2 & 0,198 & 2 & 0,198 \\
\hline S3 & 0,051 & 3 & 0,153 & 2 & 0,102 & 2 & 0,102 & 2 & 0,102 & 2 & 0,102 & & 0,153 & 4 & 0,204 & 2 & 0,102 & 2 & 0,102 \\
\hline S4 & 0,086 & 2 & 0,172 & 4 & 0,344 & 3 & 0,258 & 2 & 0,172 & 2 & 0,172 & & 0,172 & 2 & 0,172 & 2 & 0,172 & 2 & 0,172 \\
\hline S5 & 0,066 & 4 & 0,264 & 2 & 0,132 & 2 & 0,132 & 2 & 0,132 & 2 & 0,132 & 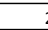 & 0,132 & 3 & 0,198 & 2 & 0,132 & 2 & 0,132 \\
\hline S6 & 0,068 & 2 & 0,136 & 2 & 0,136 & 2 & 0,136 & 2 & 0,136 & 2 & 0,136 & 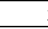 & 0,204 & 4 & 0,272 & 2 & $\begin{array}{ll}0,136 \\
\end{array}$ & 2 & 0,136 \\
\hline W1 & 0,055 & 2 & 0,11 & 2 & 0,11 & 2 & 0,11 & 4 & 0,22 & 3 & 0,165 & 2 & 0,11 & 2 & 0,11 & 3 & \begin{tabular}{l|l|}
0,165 \\
\end{tabular} & 2 & 0,11 \\
\hline $\mathrm{W} 2$ & 0,089 & 2 & 0,178 & 3 & 0,267 & 3 & 0,267 & 2 & 0,178 & 4 & \begin{tabular}{l|l}
0,356 \\
\end{tabular} & & 0,178 & 2 & 0,178 & 2 & \begin{tabular}{l|l|}
0,178 \\
\end{tabular} & 2 & 0,178 \\
\hline W3 & 0,086 & 2 & 0,172 & 3 & 0,258 & 3 & 0,258 & 3 & 0,258 & 4 & 0,344 & 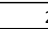 & 0,172 & 2 & 0,172 & 3 & \begin{tabular}{l|l|}
0,258 \\
\end{tabular} & 3 & 0,258 \\
\hline W4 & 0,063 & 3 & 0,189 & 2 & 0,126 & 2 & 0,126 & 3 & 0,189 & 2 & $\begin{array}{ll}0,126 \\
\end{array}$ & & 0,126 & 2 & 0,126 & 4 & \begin{tabular}{l|l}
0,252 \\
\end{tabular} & 3 & 0,189 \\
\hline W5 & 0,065 & 3 & 0,195 & 2 & 0,13 & 4 & 0,26 & 2 & 0,13 & 2 & \begin{tabular}{l|l}
0,13 \\
\end{tabular} & & 0,13 & 2 & 0,13 & 2 & \begin{tabular}{l|l}
0,13 \\
\end{tabular} & 3 & 0,195 \\
\hline W6 & 0,071 & 2 & 0,142 & 3 & 0,213 & 3 & 0,213 & 3 & 0,213 & 3 & \begin{tabular}{l|l}
0,213 \\
\end{tabular} & & 0,142 & 2 & 0,142 & 3 & \begin{tabular}{l|l|}
0,213 \\
\end{tabular} & 4 & 0,284 \\
\hline W7 & 0,137 & 3 & 0,411 & 3 & 0,411 & 4 & 0,548 & 3 & 0,411 & 3 & 0,411 & & 0,411 & 3 & 0,411 & 3 & 0,411 & 3 & 0,411 \\
\hline $\mathrm{O} 1$ & 0,101 & 4 & 0,404 & 2 & 0,202 & 3 & 0,303 & 2 & \begin{tabular}{l|l}
0,202 \\
\end{tabular} & 2 & \begin{tabular}{l|l}
0,202 \\
\end{tabular} & & 0,202 & 2 & 0,202 & 2 & \begin{tabular}{l|l}
0,202 \\
\end{tabular} & 3 & 0,303 \\
\hline $\mathrm{O} 2$ & 0,11 & 2 & 0,22 & 4 & 0,44 & 3 & 0,33 & 4 & 0,44 & 3 & 0,33 & & 0,22 & 2 & 0,22 & 2 & 0,22 & 2 & 0,22 \\
\hline $\mathrm{O} 3$ & 0,121 & 3 & 0,363 & 3 & 0,363 & 3 & 0,363 & 2 & $\begin{array}{ll}0,242 \\
\end{array}$ & 4 & 0,484 & & 0,242 & 2 & 0,242 & 2 & \begin{tabular}{l|l}
0,242 \\
\end{tabular} & 2 & 0,242 \\
\hline $\mathrm{O} 4$ & 0,09 & 2 & 0,18 & 3 & 0,27 & 4 & 0,36 & 2 & 0,18 & 2 & \begin{tabular}{l|l}
0,18 \\
\end{tabular} & & 0,18 & 2 & 0,18 & 2 & \begin{tabular}{l|l}
0,18 \\
\end{tabular} & 2 & 0,18 \\
\hline $\mathrm{T} 1$ & 0,1 & 2 & 0,2 & 2 & 0,2 & 2 & 0,2 & 2 & \begin{tabular}{l|l}
0,2 \\
\end{tabular} & 2 & 0,2 & & 0,4 & 2 & 0,2 & 2 & 0,2 & 4 & 0,4 \\
\hline $\mathrm{T} 2$ & 0,137 & 2 & 0,274 & 3 & 0,411 & 2 & 0,274 & 2 & 0,274 & 2 & 0,274 & & 0,548 & 2 & 0,274 & 2 & \begin{tabular}{l|l|}
0,274 & \\
\end{tabular} & 4 & 0,548 \\
\hline T3 & 0,274 & 2 & 0,548 & 3 & 0,822 & 2 & 0,548 & 2 & 0,548 & 2 & 0,548 & 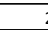 & 0,548 & 4 & 1,096 & 3 & \begin{tabular}{l|l}
0,822 \\
\end{tabular} & 3 & 0,822 \\
\hline T4 & 0,066 & 2 & 0,132 & 2 & 0,132 & 2 & 0,132 & 2 & 0,132 & 2 & \begin{tabular}{l|l|}
0,132 \\
\end{tabular} & 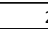 & 0,132 & 3 & 0,198 & 4 & 0,264 & 2 & 0,132 \\
\hline \multicolumn{2}{|c|}{ TOTAL } & 53 & 4,889 & 57 & 5,614 & 55 & 5,242 & 50 & 4,681 & 52 & 4,959 & 52 & 4,984 & 52 & 5,148 & 51 & 4,875 & 54 & 5,336 \\
\hline \multicolumn{2}{|c|}{ RANKING } & & 7 & & 1 & & 3 & & & 7 & & & & 4 & & 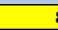 & & 2 & \\
\hline
\end{tabular}

Dari hasil perhitungan QSPM didapat total TAS (Total Attractiveness Scores) tertinggi adalah strategi $\mathrm{SO} 2$ (melakukan penjualan secara online baik menggunakan sosial media maupun situs-situs jual beli secara online) mendapatkan nilai TAS (Total Attractiveness Scores) 5,614, lalu disusul oleh strategi WT2 (Meningkatkan kualitas packaging menjadi lebih baik dan lebih menarik) TAS bernilai 5,336, lalu posisi tiga strategi WO1 (Menjadikan tempat kerja menjadi lebih nyaman dengan menata ulang pabrik sehingga dapat terlihat lebih rapi dan bersih dan melakukan pernerapan 5R) nilai TAS adalah 5,242.

Atas dasar luaran analisa QSPM maka, melalui brainstorming, strategi yang telah diprioritaskan, diturunkan menjadi rumusan sasaran strategis dan penentuan indicator pencapaiannya sebagai berikut :

Tabel 6. Sasaran Strategis dan Indikator Pencapaian

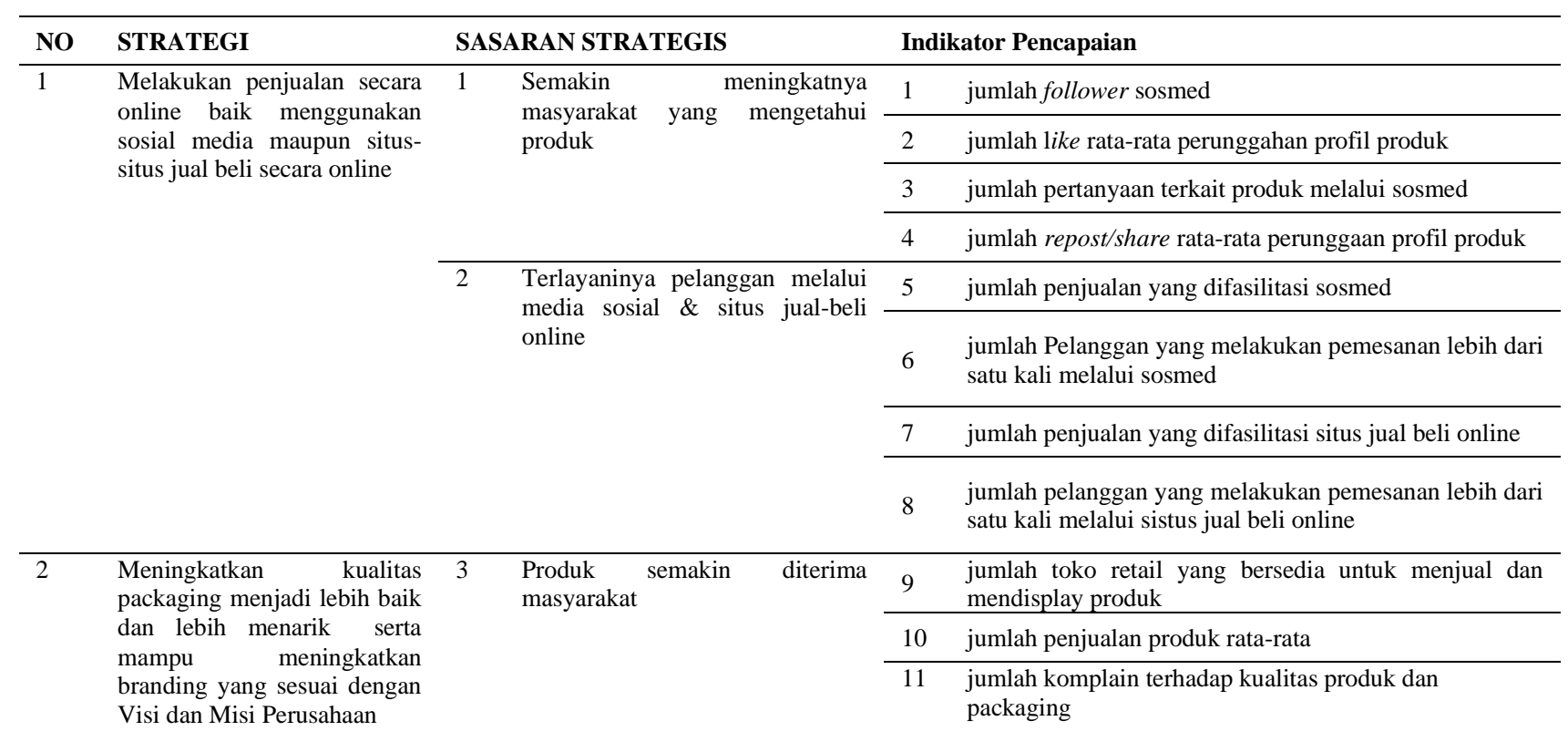




\begin{tabular}{|c|c|c|c|c|c|}
\hline \multirow{2}{*}{$\begin{array}{l}\text { NO } \\
3\end{array}$} & \multirow{5}{*}{$\begin{array}{l}\text { STRATEGI } \\
\text { Menjadikan tempat kerja } \\
\text { menjadi lebih nyamann } \\
\text { dengan menata ulang pabrik } \\
\text { sehingga dapat } \\
\text { terlihat lebih rapi dan bersih } \\
\text { dan melakukan pernerapan 5R }\end{array}$} & \multicolumn{2}{|c|}{ SASARAN STRATEGIS } & \multicolumn{2}{|c|}{ Indikator Pencapaian } \\
\hline & & \multirow[t]{3}{*}{4} & \multirow[t]{3}{*}{$\begin{array}{l}\text { Meningkatnya motivasi } \text { kerja } \\
\text { karyawan }\end{array}$} & 12 & jumlah turnover pegawai \\
\hline & & & & 13 & rata-rata jumlah hari perbulan ijin tidak masuk karyawan \\
\hline & & & & & $\begin{array}{l}\text { rata-rata jumlah hari perbulan ijin tidak masuk karyawan } \\
\text { karena sakit }\end{array}$ \\
\hline & & \multirow[t]{3}{*}{5} & \multirow{3}{*}{$\begin{array}{l}\text { Menurunnya tingkat downtime } \\
\text { permesinan }\end{array}$} & 15 & jumlah jam downtime akibat mesin tidak beroperasi \\
\hline & & & & 16 & jumlah mesin yang tidak berfungsi normal \\
\hline & & & & 17 & jumlah peralatan kerja yang dilaporkan hilang \\
\hline & & 6 & Terjaminnya target produksi & & target produksi rata-rata \\
\hline
\end{tabular}

\section{Kesimpulan}

Penjualan UD Darmaji pada lima tahun terakhir mengalami penurunan, berbagai faktor yang menyebabkannya salah satunya dalah ketatnya persainan, daya beli masyarakat yang menurun serta diperparah dengan terjadinya bencana non alam penyebaran Covid 19 yang terjadi secara global. Dalam menyikapi hal tersebut maka dilakukan penelitian untuk memberikan usulan strategi rekomendasi bagi UD Darmaji untuk mampu bertahan dan upaya meningkatkan penjualan.

Melalui pendekatan integratif SWOT dan QSPM penelitian ini berhasil merumuskan rekomendasi strategi bagi UD Darmaji. Melalui analisa SWOT posisi strategis UD Darmaji adalah pada kuadran turn-around (lihat Gambar 1) dimana strategi yang dirumuskan harus mampu membalikkan penurunan profitabilitas kembali menuju pemulihan dan mencapai masa depan yang berkelanjutan. Matriks SWOT merekomendasikan 9 (sembilan) alternatif strategi, dan untuk menseleksi prioritas strategi yang diimplementasikan melalui pendekatan analisa QSPM, maka urutan prioritas rekomendasi strategi bagi UD Darmaji adalah : strategi melakukan penjualan secara online baik menggunakan sosial media maupun situssitus jual beli secara online; lalu strategi untuk meningkatkan kualitas packaging menjadi lebih baik dan lebih menarik; lalu prioritas strategi selanjutnya adalah menjadikan tempat kerja menjadi lebih nyaman dengan menata ulang pabrik sehingga dapat terlihat lebih rapi dan bersih dan melakukan penerapan 5R (lihat tabel 4 dan gambar 2) . dari tiga rekomendasi utama strategi bagi UD Darmaji tersebut, ditetapkan 3nam sasaran strategi utama dengan total 18 indikator pencapaian (lihat tabel. $5)$.

\section{Ucapan Terima Kasih}

Ucapan terima kasih kami sampaikan kepada manajemen UD. Darmaji beserta karyawan yang telah bersedia menjadi subjek dalam penelitian ini, selanjutnya kami sampaikan terima kasih kepada LPPM (Lembaga Penelitian dan Pengabdian Masyarakat) Universitas Katolik Darma Cendika dan LiMaCC sebagai donatur dalam pendanaan penelitian ini.

\section{Daftar Pustaka}

A Zulkarnain, D Wahyuningtias, \& T S Putranto (2018) Analysis of IFE, EFE and QSPM matrix on business development strategy. IOP Conf. Series : Eart and Environmental Science, 126.

Achmadi, N. S., Andriani, D., \& Sudirman, M. A. (2020). Strategi Pengelolaan Akomodasi Berbasis Ekotourisme Di Tanjung Bayang Makassar Menggunakan Matrik SWOT Dan QSPM. Journal FAME: Journal Food and Beverage, Product and Services, Accomodation Industry, Entertainment Services, 3(2).

Al-Refaie, A., Sy, E., Rawabdeh, I., \& Alaween, W. (2016). Integration of SWOT and ANP for effective strategic planning in the cosmetic industry. Advances in Production Engineering \& Management, 11(1), 49.

Astina, S. T., \& Mawardi, M. K. (2016). Analisis Segmentation, Targeting, dan Positioning dalam Rangka Meningkatkan Daya Saing Melalui Strategi Pemasaran di Toko Pia Cap Mangkok Cabang Semeru. Jurnal Administrasi Bisnis, 39(2), 57-66.

David, Fred R. 2005. Manajemen Strategis: Konsep. Jakarta : Salemba Empat

Maulidya Alfi A.Z , Vira Rizky dkk. (2018) Analisis Segmenting, Targeting, Positioning, dan Analisis SWOT Sebagai Strategi Pemasaran Kopi Karlos (Studi pada Produsen Kopi Karlos Desa Donowarih Kecamatan Karangploso Kabupaten Malang ). Jurnal Cakrawala, 12(1),41-62

Mujiastuti, R., Latifah, R., \& Hendra. (2019). Penentuan Jenis Strategi Pemasaran Menggunakan Metode SWOT dan QSPM Pada UMKM Fashion di Kelurahan Penggilingan Berbasis Teknologi. Jurnal Ilmiah FIFO, XI(1), 52-64.

Nuary, N. S. (2016). Strategi Pemasaran dengan Pendekatan Analisis SWOT pada PT. Super Sukses Motor Banjarmasin. Jurnal Ilmiah Ekonomi Bisnis, 2(1), 30-42.

Purwanti, E. (2013). Pengaruh karakteristik wirausaha, modal usaha, strategi pemasaran terhadap perkembangan UMKM di Desa Dayaan dan Kalilondo Salatiga. Among Makarti, 5(9).

Putri, N. E., Astuti, R., \& Putri, S. A. (2014). Perencanaan Strategi Pengembangan Restoran Menggunakan Analisis SWOT Dan Metode QSPM 
(Quantitative Strategic Planning Matriks) (Studi Kasus Restoran Big Burger Malang). Industria: Jurnal Teknologi dan Manajemen Agroindustri, 3(2), 93-106.

Rismawati, F. F., Wahyuni, S., \& Widodo, J. (2019). Strategi Pemasaran STP (Segmenting, Targeting, Positioning) Larissa Aesthetic Center Cabang Jember. Jurnal Pendidikan Ekonomi: Jurnal Ilmiah Ilmu Pendidikan, Ilmu Ekonomi dan Ilmu Sosial, 13(2), 68-72.

Saaty,T.L (1994). The Fundamentals of Decision Making Priority Theory With the Analytic Hierarchy Process, RWS Publication, Pittsburgh.

Sari, R. I., \& Budiani, S. R. (2017). Analisis Strategi Pemasaran Industri Tenun di Desa Wisata Gamplong Kabupaten Sleman. Majalah Geografi Indonesia, 32(1), 98-107.

Shahri, M. H., \& Sarvestani, M. N. (2020). Business model innovation as a turnaround strategy. Journal of Strategy and Management.

Sluismans, R., Lommelen, T., \& den Hertog, F. (2010). The use of SWOT as a tool to stimulate strategic conversation in SMEs. In IIE Annual Conference. Proceedings (p. 1). Institute of Industrial and Systems Engineers (IISE). 